\title{
Evaluation of the KEMRI Hep-cell II test kit for detection of hepatitis B surface antigens in Tanzania
}

\author{
ANDREW M. KILALE*, NYAGOSYA S. RANGE, PROSPER H. NGOWI, AMOS M. KAHWA and \\ SAYOKI G. MFINANGA \\ National Institute for Medical Research, Muhimbili Medical Research Centre, P. O. Box 3436, Dar es Salaam, \\ Tanzania
}

\begin{abstract}
Hepatitis B surface antigen (HBsAg) is one of the most important serological markers used to diagnose acute and chronic hepatitis B infection. The objective of the current evaluation was to assess the operational characteristics of the Kenya Medical Research Institute (KEMRI) Hep-cell II against an ELISA Exsym HBsAg in the detection of hepatitis B surface antigens. To evaluate the Hepcell II test, blood samples were collected from blood donors and processed for detection of HBsAg using Hep-cell II based on the test principle and procedure outlined by the manufacturer. ELISA Axsym HBsAg test was used as golden standard. Of the 400 samples tested, 287 (71.8\%) were positive by Hep-cell test and 295 (73.8\%) were positive by the ELISA Axsym. Hep-cell test had a sensitivity of $98.6 \%$ and specificity of $95.96 \%$. Similar values of sensitivity and specificity of the Hep-cell test were obtained even when Bayesian Analysis Model was applied. The positive and negative predictive values of Hep-cell test were $98.61 \%$ and $95.96 \%$, respectively. The positive and negative diagnostic likelihood ratios of Hep-cell test were $24.4 \%$ and 0.0145 , respectively. In conclusion, the Hep-cell test is useful for detecting hepatitis B virus and the high likelihood ratio observed suggests that it may be useful in blood screening. However, it may be necessary to evaluate for cost-effectiveness and robustness in field conditions before the test is recommended for use.
\end{abstract}

Keyword: Hepatitis B, antigen, Hep-Cell test, diagnosis, KEMRI, Tanzania

\section{Introduction}

Hepatitis is commonly caused by infection with one of the five viruses, namely Hepatitis A, B, C, D and E. The viruses can cause an acute disease with symptoms lasting for several weeks. Hepatitis B virus (HBV) is the cause of the most serious type of viral hepatitis and the only for which a vaccine is available (WHO, 2000; Hou et al., 2005; Kao, 2008). It is the major cause of chronic hepatitis, cirrhosis and hepatocellular carcinoma (HCC) worldwide (Kao, 2008). Global estimate shows that chronic HBV infection affects more than 350 million people and 50 million new cases are diagnosed annually (WHO, 2000; Hou et al., 2005).

$\mathrm{HBV}$ is endemic and poses a grave public health problem in Africa where it is mainly transmitted from mother to baby or during childhood. Studies conducted in Tanzania show that HBV and respective seromarkers are increasingly prevalent (Msuya et al., 2006). Pellizzer et al. (1992) reported prevalence of HBV and of any HBV marker in 1004 subjects aged one to 76 years living in urban and rural areas in Tanzania to be $4.4 \%$ and $37.0 \%$, respectively. Matee et al. (2006), in a study involving blood donors at Muhimbili National Hospital in Dar es Salaam reported the hepatitis B and C virus sero-prevalence of $8.8 \%$ and $1.5 \%$, respectively. The seroprevalences among HIV seronegative blood donors were $8.7 \%$ for $\mathrm{HBV}$, and $1.6 \%$ for HCV (Matee et al., 2006). Similarly, in a study conducted by Hasegawa et al. (2006) among 457 blood donors showed that the prevalence of HBV was

\footnotetext{
* Correspondence: Andrew M. Kilale; E-mail: kilale@yahoo.com
} 
13.6\%. This shows that HBV presents a higher residual risk of transmission by transfusion (Allain, 2004).

Infection with $\mathrm{HBV}$ is associated with characteristic changes in the serum levels of hepatitis $B$ antigens and antibodies. The markers are used to define different clinical stages of HBV infection. Diagnosis of HBV infection is usually done through serological and virological markers. Hepatitis B surface antigen (HBsAg) is the hallmark of HBV infection and is the first serological marker to appear in acute hepatitis $\mathrm{B}$, and persistence of $\mathrm{HBsAg}$ for more than 6 months suggests chronic HBV infection (Krajden et al., 2005; Kao, 2008).

In most high HBV endemic countries, prevention of viral transmission by transfusing safe blood is necessary (Challine et al., 2008). However, kits for screening HBsAg are usually imported and are expensive; hence, it has been difficult to screen all the donated and patient blood samples for HBV infection (Kuhns et al., 2006; Kao, 2008). Given the multitude of available tests and the complexity of clinical management, it is therefore important that there is coordination among clinicians, laboratory personnel and researchers to define optimal laboratory diagnostic and monitoring assays so that appropriate tests are used to maximize HBV prevention and optimize treatment outcomes (Krajden et al., 2005).

The KEMRI Hep-cell II (HEPCELL®) is produced by the Kenya Medical Research Institute (KEMRI) based on purified HBsAg from blood plasma. It is a chromatographic immunoassay for direct qualitative detection of Hepatitis B type virus surface antigen (HBsAg) in human serum plasma. On average it takes 5-20 minutes to obtain results. The kit is stable and potent for one year whether kept $4{ }^{\circ} \mathrm{C}, 37^{\circ} \mathrm{C}$ or room temperature (Okoth et al., 1999). The objective of the current evaluation was to assess the operational characteristics of the Hep-cell II test from KEMRI against an ELISA Exsym HBsAg for the purpose of advising the government, scientific community and other interested parties on the use of the test in Tanzania.

\section{Materials and Methods}

\section{Description of the KEMRI Hep-cell test}

The main constituents of the KEMRI Hep-cell test kit are fixed sheep erythrocytes sensitized with anti-HBs obtained from HBsAg-immunized guinea pigs. In the presence of HBsAg in the test sample, the sensitized sheep erythrocytes formed a complex and agglutinated (passive agglutination). This could be read with the naked eye or under a mirror. When diluted, test serum was mixed with anti-HBs coated sheep erythrocytes in a microtiter plate, the coated sheep erythrocytes agglutinated if the test serum contained HBsAg. The coated sheep erythrocytes settled and formed a button-like precipitate in the bottom of the well of the micro plate. Positivity of HBsAg in the test serum was determined by the appearance of these agglutination patterns.

\section{ELISA Axsym HBsAg (V2)}

Axsym HBsAg (V2) is based on the microparticle enzyme immunoassay (MEIA) technology. When HBsAg is present in the sample it binds to the Anti-HBs, forming an antibodyantigen-antibody complex in the reaction mixture. When the conjugate is added, it binds with any microparticle-bound antibody-antigen-antibody-complex. After addition of the substrate, the enzyme-labelled conjugate catalyzes the removal of a phosphate group from the substrate forming the fluorescent product, 4-methlumbelliferone which is measured by the META optical assembly (Abbott Laboratories, 2004). 


\section{Collection and processing of blood samples}

This study was carried out from February to June 2005. $5 \mathrm{ml}$ of blood samples were collected from blood donors at Muhimbili National Hospital, Mbeya Referral Hospital, Kilimanjaro Christian Medical Centre and Bugando Medical Centre. The samples were collected from various categories of blood donors including voluntary, paid and family/relative by trained personnel using the Becton-Dickinson (Rutherford, NJ) EDTA vacutainer blood collection system for whole blood and plasma.

The blood was used to test for HBV infection using the Hep-cell test and ELISA Axsym HBsAg test as the comparison test. To minimize false positive or false negative retesting was blindly done by a different person using Hep-cell test kit. Unfortunately, no HIV test results were obtained from the participating hospitals. All blood donors were informed on the intention to include HBV testing in the collected samples. Specimens were processed by standardized methods and tested following the manufacturer's instructions.

\section{Test procedure}

The freeze-dried Hep-cell reagent was reconstituted in 2, $5 \mu$ l of the diluent for 100 test screening patterns. Screening procedure involved preparing a microplate $(10 \times 12$ or $8 \times 12$ wells), for a purpose of using 4-wells in a row for each individual test serum and an additional row for the positive control. Twenty five millilitres of the diluent was then added using a dropper into 4 -wells in a row. Using the diluter, $25 \mathrm{ml}$ of the test serum was picked and added into the first well. Serially, the mixture was diluted up to the $4^{\text {th }}$ well before being discarded. Twenty five millilitres of well-mixed Hep-cell reagent (reconstituted, sensitized SRBC) was added into the last well in the dilution series (1:16). The content was then mixed thoroughly on a plate mixer or by tapping the corners of the microplate. The mixture was incubated at room temperature $\left(20-30^{\circ} \mathrm{C}\right)$ for $1-2$ hours and the test was read on a white background.

Agglutination in the last well was regarded as a clear positive screening result for HBsAg. Samples showing agglutination in the $4^{\text {th }}$ (last) well were also regarded as HBsAg screening test positive. Those showing no agglutination but a clear button of cells in the $4^{\text {th }}$ well were regarded as negative for HBsAg. Tests with weak reacting results were repeated with the same kit and then confirmed by Axsym ELISA assays.

\section{Sample size}

The sample size was determined based on assumption that the test has a specificity and sensitivity of $99 \%$ and $90 \%$, respectively (Okoth et al., 1999). The maximum acceptable size of standard error tolerated was estimated to be within \pm 0.03 . Preference of the $95 \%$ confidence interval to be not wider than \pm 0.03 , estimation of the minimum sample size for blood donors to be enrolled into the study was calculated to be 100 blood donors. However, the sample size was doubled to 400 to enable determination of the prevalence of HBV based on test.

\section{Data analysis}

Data were entered and analyzed using SPSS version 13.0. Sensitivity, specificity and predictive values were calculated to describe properties of the test. Diagnostic likelihood ratios (DLR) were used as alternative statistics for summarizing the diagnostic accuracy of the Hep-Cell test. DLRs summarizes how many times more (or less) likely patients with the disease are to have that particular result than patients without the disease (Hu et al., 1999). A likelihood ratio greater than one indicates that the test result is associated with the presence 
of the disease, whereas a likelihood ratio less than one indicates that the test result is associated with the absence of disease. The further likelihood ratios are from each one, the stronger the evidence for the presence or absence of disease. When test results were either positive or negative the two likelihood ratios were called the positive and negative likelihood ratios, respectively.

\section{Ethical consideration}

Before conducting the study, ethical clearance was sought from and granted by the Medical Research Coordinating Committee of the National Institute for Medical Research. Administrative permission was sought from authorities of the institutions where blood samples were collected. A written consent was obtained from all participating clients.

\section{Results}

A total of 400 samples from blood donors were collected from the four referral hospitals. The distribution of the blood donors recruited in each hospital is shown in Table 1. Of the 400 samples tested, $287(71.8 \%)$ were positive by Hep-cell test kit and 295 (73.8\%) by ELISA Axsym HBsAg test. Fourteen samples (3.5\%) were indeterminate by the Hep-cell test kit and none was by the ELISA Axsym HBsAg test (Table 2). Of the 14 (57.1\%) indeterminate samples, eight tested positive by the ELISA Axsym HBsAg test and the other six (42.9\%) tested negative. However, the differences in the proportion of positive samples by the two test kits was not statistically significant $\left(\chi^{2}=0.33, \mathrm{df}=1, \mathrm{p}>0.05\right)$. Seven $(50 \%)$ out of the 14 indeterminate samples by Hep-cell test were from $\mathrm{MNH}$ and five (35\%) (5/14) were from BMC (Table 3).

Table 1: Distribution of the number of recruited blood donors by Hospitals

\begin{tabular}{lll}
\hline Name of the Laboratory & Number tested & Percent \\
\hline 1. Muhimbili National Hospital & 148 & 37.0 \\
2. Bugando Medical Centre & 152 & 38.0 \\
3. Mbeya Referral Hospital & 50 & 12.5 \\
4. Kilimanjaro Christian Medical Centre & 50 & 12.5 \\
\hline Total & $\mathbf{4 0 0}$ & $\mathbf{1 0 0 . 0}$ \\
\hline
\end{tabular}

Table 2: Comparison of results between Hep-Cell and the ELISA Axsym HBsAg tests

\begin{tabular}{|c|c|c|c|c|c|c|}
\hline \multirow{5}{*}{$\begin{array}{l}\text { ELISA } \\
\text { HBsAg test }\end{array}$} & \multicolumn{4}{|c|}{ Hep-Cell test } & \multicolumn{2}{|r|}{ Total } \\
\hline & & Results & ?ositive & Negative & Indeterminate & \\
\hline & Axsym & & (n) $\quad(\%)$ & (n) $\quad(\%)$ & (n) $\quad(\%)$ & (n) $\quad(\%)$ \\
\hline & & Negative & $4 \quad(1.4)$ & $95(96.0)$ & $6 \quad(42.9)$ & 105 (26.2) \\
\hline & & Positive & $283(98.6)$ & $4 \quad(4.0)$ & $8(57.1)$ & $295(73.8)$ \\
\hline Total & & & 287 & 99 & 14 & 400 \\
\hline
\end{tabular}

A summary of the calculation of the diagnostic sensitivity and specificity of the Hep-cell test kit based on the 386 samples from blood donors whom the test gave conclusive results is shown on Table 4 . This excludes the 14 samples which were indeterminate. 
Table 3: Distribution of the results by Hep-Cell test among the involved Hospitals

\begin{tabular}{llllll}
\hline \multirow{2}{*}{ Hospitals } & \multicolumn{2}{l}{ Hep-Cell test results } & \multicolumn{2}{l}{ Total } \\
\cline { 2 - 5 } & Positive & Negative & Undetermined & Total \\
\hline & $(\mathrm{n})(\%)$ & $(\mathrm{n})(\%)$ & $(\mathrm{n})(\%)$ & $(\mathrm{n})(\%)$ \\
Muhimbili National Hospital & $127(44.3)$ & $14(14.1)$ & $7(50.0)$ & $148(37.0)$ \\
Bugando Medical Centre & $63(22.0)$ & $84(84.8)$ & $5(35.7)$ & $152(38.0)$ \\
Mbeya Referral & $48(16.7)$ & $1(1.0)$ & 1 & $(7.1)$ & $50(12.5)$ \\
Kilimanjaro Christian Medical Centre & $49(17.1)$ & $0(0.0)$ & $1(7.1)$ & $50(12.5)$ \\
\hline Total & $\mathbf{2 8 7}$ & $\mathbf{9 9}$ & $\mathbf{1 4}$ & $\mathbf{4 0 0}$ \\
\hline
\end{tabular}

Similar values of sensitivity (98.6\%) and specificity $(95.96 \%)$ of the Hep-cell test were obtained even when Bayesian Analysis Model (Hu et al., 1999) was applied. Based on the model, the test had a Positive Predictive Value (PPV) and Negative Predictive Value (NPV) of $98.61 \%$ and $95.96 \%$, respectively. The test positive diagnostic likelihood ratio (PDLR) was 24.4 and negative likelihood ratio (NDLR) was 0.0145 . Hence the prevalence of hepatitis B virus infection among the study community based on the test was $74.4 \%$.

Table 4: Diagnostic sensitivity and specificity of Hep-cell test kit

\begin{tabular}{ll|l|l}
\hline & \multicolumn{2}{l}{ ELISA Axsym HBsAg test } \\
\cline { 3 - 4 } & & Positive $\left(\mathrm{n}_{1}=\mathrm{a}+\mathrm{c}=287\right)$ & Negative $\left(\mathrm{n}_{2}=\mathrm{b}+\mathrm{d}=99\right)$ \\
\hline Hep-cell & Positive & 283 & 4 \\
test results & & $\mathrm{a}$ & $\mathrm{b}$ \\
& \multirow{2}{*}{ Negative } & $\mathrm{c}$ & $\mathrm{d}$ \\
& 4 & 95 \\
& & Hep-cell test sensitivity & Hep-cell test specificity \\
& & $\mathrm{a} / \mathrm{n}_{1} \times 100=283 / 287 \times 100=98.6 \%$ & $\mathrm{~d} / \mathrm{n}_{2} \times 100=95 / 99 \times 100=95.96 \%$ \\
\hline
\end{tabular}

NB: $a=$ True positive, $b=$ False positive, $c=$ False negative, $d=$ True negative

\section{Discussion}

In blood screening settings, it is very important not to miss a disease which is serious and potentially treatable like HBV infection; it would be better to use a test which has greater sensitivity and enable to pick up as many individuals with the infection as possible. This will minimize chances or risks of transfusing infected blood to the recipient. A simple diagnostic test is one where the results of an investigation are used to classify patients into two groups, either presence or absence of the infection (Altman et al., 1994). A diagnostic test is valid if it detects most people with or without the target disorder (Greenhalgh, 1997). Thus the usefulness of a test depends on the context in which it is used.

The detection rates of Hep-cell test in our study were similar to those of Axsym HBsAg as reported elsewhere by other studies (Matsuo et al., 1998; Webber et al., 2003; Moerman et al., 2005). In these studies, Axsym HBsAg had a sensitivity of $96.7 \%$, specificity of $100 \%$, PPV and NPPV of $78.7 \%$.

The use of HbsAg in the diagnosis of HBV is also well recommended by Kuhns et al. (2004) in a study that tried to understand the relationship between HBsAg and HBV deoxyribonucleic acid (DNA) concentrations in HBV-infected blood donors. Japhet et al. (2011) evaluated other five different serological makers of HBV infection for their reliability of using HBsAg marker alone in diagnosis of HBV infection among blood donors and to 
detect the serological evidence of the infection at the window period. Their findings corroborated well by earlier reports that testing blood donors for HBsAg alone is not sufficient to eliminate HBV from blood supply (Muhlbacher et al., 2001; Kumar et al., 2007). As the KEMRI Hep-cell test emphasizes the use of $\mathrm{HbsAg}$, it is envisaged that it also presents a valuable alternative in the future of blood screening in developing countries.

In our analysis, we did not include age (Seef et al., 2006), sex, HIV and other infections (Richardson et al., 1994) which are some of the important confounding factors to the performance of any diagnostic test. The major challenge of Hep-cell test lies on its operational characteristics such as cost, ease of use, storage requirements and equipment required. Similarly, issues of cost-effectiveness may be important to be addressed in settings other than Kenya, the country where it was developed.

Although an ideal test of $100 \%$ sensitivity and $100 \%$ specificity does not exist, the Hep-cell test has shown to have both high sensitivity and specificity. The test has also shown to have a high likelihood ratio suggesting that it can provide a change from pre-test to posttest probabilities and thus more likely to be useful in clinical practice. The findings suggest that the Hep-cell test is effective for clinical HBsAg screening of blood donors for HBsAg prior to a blood transfusion.

\section{Conflict of interest}

The authors have no any conflict of interest and declare that the reported findings have not been influenced by financial source.

\section{References}

Abbott Laboratories (2004) HAVAB-M 2.0. List No. 5E20. 69-6582/R4, HAVAB®-M 2.0. Customer Service (USA): 1-877-4ABBOTT. Diagnostics Division, Abbott Park, IL 60064 USA

Allain, J.P. (2004) Occult hepatitis B virus infection: implications in transfusion. Vox Sang 86, 83-91.

Challine, D., Chevaliez, S. \& Pawlotsky, J.M. (2008) Efficacy of serologic marker screening in identifying hepatitis B virus infection in organ, tissue, and cell donors. Gastroenterology 135, 1185-1191.

Greenhalgh, T. (1997) How to read a paper: Papers that report diagnostic or screening tests. British Medical Journal 315, 540-543.

Hasegawa, I., Tanaka, Y., Kurbanov, F., Yoshihara, N., El-Gohary, A., Lyamuya, E., Matee, M., Magessa, P., Fujiwara, K., Ozasa, A., Sugauchi, F., Orito, E., Ueda, R., Mizokami, M. (2006) Molecular epidemiology of hepatitis B virus in the United Republic of Tanzania. Journal of Medical Virology 78, 1035-1042.

Hou, J., Liu, Z., Gu, F. (2005) Epidemiology and prevention of Hepatitis B Virus infection. International Journal of Medical Sciences 2, 50-57.

Japhet, M.O., Olufisayo, A.A., Donbraye, E. \& Adewumi, M.O. (2011) Hepatitis B Core IgM antibody (anti-HBcIgM) among hepatitis B surface antigen (HBsAg) negative blood donors in Nigeria Virology Journal 8, 513.

Kao, J.H. (2008) Diagnosis of hepatitis B virus infection through serological and virological markers. Expert Review of Gastroenterology E Hepatology 2(4):553-62. 
Krajden, M., McNabb, G. \& Petric, M. (2005) The laboratory diagnosis of hepatitis B virus. Canadian Journal of Infectious Diseases E Medical Microbiology 16(2):65-72.

Kumar, H., Gupta, P.K., Jaiprakash Brig, M (2007) The role of anti-HBc IgM in Screening of Blood Donors. Medical Journal Armed Forces India 63:350-352.

Matee, M.I.N., Magesa, P.M. \& Lyamuya, E.F. (2006) Seroprevalence of human immunodeficiency virus, hepatitis $B$ and $C$ viruses and syphilis infections among blood donors at the Muhimbili National Hospital in Dar es Salaam, Tanzania. Biomed Central Public Health 6, 21.

Matsuo, T., Shinzawa, H., Togashi, H., Aoki, M., Sugahara, K., Saito, K., Saito, T., Takahashi, T., Yamaguchi, I., Aoyama, M. \& Kamada, H. (1998) Highly sensitive Hepatitis B Surface Antigen detection by measuring stable nitroxide radical formation with ESR spectroscopy. Free Radical Biology and Medicine 25, 929-935.

Moerman, B., Moons, V., Sommer, H., Schmitt, Y. \& Stetter, M. (2004) Evaluation of sensitivity for wild type and mutant forms of hepatitis B surface antigen by four commercial HBsAg assays. Clinical Laboratory 50, 159-162.

Msuya, S.E., Mbizvo, E.M., Hussain, A., Sam, N.E. \& Stray-Pedersen, B. (2006) Seroprevalence of hepatitis B and C viruses among women of childbearing age in Moshi Urban, Tanzania. East African Medical Journal 83, 91-94.

Muhlbacher, A., Zdunek, D., Melchior, W. \& Michl, U. (2001) Is infective blood donation missed out without screening for antibody to hepatitis B core antigen and/or hepatitis B virus DNA. Vox Sang 81,139.

Okoth, F.A., Kaiguri, P.M., Mathenge, E., Tuei, J., Muchiri, S., Owino, N., Kamau, G., Kulundu, J., Njuguna, A., Tukei, P.M., Yano, M. \& Naruse, T. (1999) KEMRI Hep-cell II hepatitis B surface antigen screening kit. East African Medical Journal 76, 530-532.

Pellizzer, G., Blè, C., Zamperetti, N., Stroffolini, T., Upunda, G., Rapicetta, M., Chionne, P., Villano, U., Fabris, P. \& de Lalla, F. (1994) Serological survey of hepatitis B infection in Tanzania. Public Health 108, 427-431.

Richardson, I., Melester, T. \& Gold, D. (1994) Liver Disease and HIV. Gay Men's Health Crisis. Treatment Issues 8, 5 .

WHO (2000) Hepatitis B. WHO Fact Sheet No. 204. http://www.islamset.com/healnews/Bulletin/Heaptitis.html 